\title{
FORCED EXPIRATORY VOLUME IN ONE SECOND (FEV-1) PADA PENDUDUK YANG TINGGAL DI DATARAN TINGGI
}

\author{
${ }^{1}$ Ray E. Molenaar \\ ${ }^{2}$ J. J. V. Rampengan \\ ${ }^{2}$ S. R. Marunduh
}

\author{
${ }^{1}$ Kandidat Skripsi Fakultas Kedokteran Universitas Sam Ratulangi Manado \\ ${ }^{2}$ Bagian Fisiologi Fakultas Kedokteran Universitas Sam Ratulangi Manado \\ Email: raymolenaar@yahoo.com
}

\begin{abstract}
Livingin highlands as geographical factors related to the nature of the climate influences the shape of the human body. There is a tendency of people who live in the highlands have bigger circle chest and lungs than the people who live in the lowlands. Numerous studies shows the degree of lung function in people living at highlandsare greater than the people living in the lowlands. This study aims to determine the profile of FEV-1 of the people who lives in highlands. This is a descriptive type of research that uses distribution tables. The subject of this researchare people aged 20-70 years made up of 30 womens who live in the highlands. The data is obtained through the measurement of FEV-1 using Spirometer Sibel TS8248 / 1. Different fromthe results of previous studies and based on the results of the measurement and distribution table of FEV-1 obstructive degree, 29 people of the population have normal value and 1 person has a mild obstructive value. The is, almost all of the subjectsthat were studied has normal value of FEV-1.
\end{abstract}

Keywords: FEV-1, Highlands.

\begin{abstract}
Abstrak: Ketinggian tempat tinggal sebagai faktor geografis yang berhubungan dengan sifat iklim berpengaruh terhadap bentuk tubuh. Ada kecenderungan orang-orang yang tinggal di dataran tinggi memiliki lingkaran dada dan paru-paru yang lebih besar dari pada orang-orang yang tinggal di dataran rendah.Sejumlah penelitian menunjukkan derajat fungsi paru pada penduduk yang tinggal di dataran tinggi lebih besar dari pada penduduk yang tinggal di dataran rendah.Penelitian ini bertujuan untuk mengetahui gambaran hasil pengukuran FEV-1 pada penduduk yang tinggal di dataran tinggi.Jenis penelitian ini bersifat deskriptif dengan menggunakan tabel distribusi.Subjek dari penelitian ini berusia 20-70 tahun terdiri dari 30 orang perempuan yang tinggal di dataran tinggi.Data di peroleh melalui pengukuran FEV-1 menggunakan spirometer SIBEL TS8248/1.Berbeda dengan hasil penelitian sebelumnya dan berdasarkan hasil pengukuran dan tabel distribusi derajat obstruktif FEV-1, 29 orang penduduk memiliki nilai normal dan 1 orang memiliki nilai obstruktif ringan.Kesimpulan dari hasil peneletian ini adalah, rata-rata subyek yang diteliti memiliki nilai FEV-1 normal.
\end{abstract}

Kata kunci: FEV-1, dataran tinggi.

Sistem pernapasan dibentuk oleh beberapa struktur. Seluruh struktur tersebut terlibat dalam proses respirasi eksternal yaitu proses pertukaran oksigen (O2) antara atmosfer dan darah serta pertukaran karbondioksida (CO2) antara darah dan atmosfer.

Respirasi eksternal adalah proses pertukaran gas antara darah dan atmosfer sedangkan respirasi internal adalah proses pertukaran gas antara darah sirkulasi dan sel jaringan. Respirasi internal (pernapasan selular) berlangsung diseluruh sistem tubuh.Yang termasuk struktur utama system pernapasan adalah saluran udara pernapasan, terdiri dari saluran napas atas dan saluran napas bawah, serta paru (parenkim paru). 


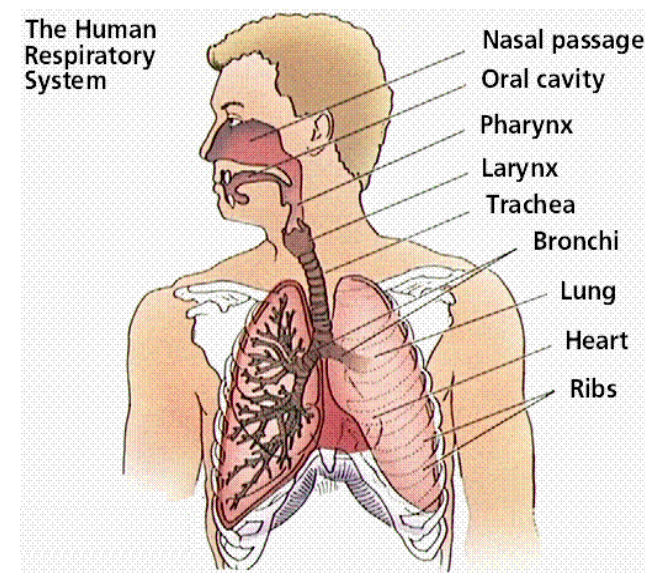

Gambar 1. Anatomi saluran pernapasan. Sumber : (Franklin Insitute of Medicine. Respiratory System : Oxygen Delivery System. Franklin : The institute; 1996).

Yang disebut sebagai saluran napas atas adalah (1) nares, hidung bagian luar (external nose), (2) hidung bagian dalam (internal nose), (3) sinus paranasal, (4) faring, (5) laring.Saluran napas bawah adalah (1) trakea, (2) bronki dan bronkioli.Yang dimaksud dengan parenkim paru adalah organ berupa kumpulan alveoli yang mengelilingi cabang-cabang pohon bronkus. Paru kanan terdiri dari tiga bagian, yaitu lobus atas kanan, lobus tengah kanan, dan lobus bawah kanan. Setiap lobus mempunyai bronkus lobusnya masingmasing. Paru kiri mempunyai dua lobus, yaitu lobus atas kiri dan lobus bawah kiri dan setiap lobus juga mempunyai bronkus lobusnya masing-masing seperti paru kanan $(1,2,3)$.

Volume Dinamis Paru, yaitu: $(4,5)$

a. Forced Vital Capacity (FVC) yaitu volume udara maskimum yang dapat dihembuskan secara paksa, yang dapat kita ketahui kapasitas vital paksa dari sesorang. Umumnya dicapai dalam 3 detik. Nilai normalnya 4 liter.

b. Forced Expired Volume in one second (FEV-1)yaitu volume udara yang dapat dihembuskan paksa pada satu detik pertama. Nilai normalnya 3,2 liter. Orang sehat dapat menghembuskan 7580\% atau lebih FVC dalam satu detik. Rasio FEV-1/FVC = 75-80\%
Dataran tinggi adalah dataran luas yang letaknya di daerah tinggi atau pegunungan.Dataran tinggi terbentuk sebagai hasil erosi dan sedimentasi. Dataran tinggi dinamakan juga plato (plateu). Dataran tinggi bias juga terjadi oleh bekas kaldera luas, yang tertimbun material dari lereng gunung sekitarnya.(6)

Daerah dataran tinggi memiliki stress lingkungan yang unik dan berbeda dengan dataran rendah, terutama dalam hipoksia dan suhu udara yang rendah. Penduduk di dataran tinggi memerlukan kebutuhan jenis dan besar aktifitas fisik yang berbeda dengan penduduk yang tinggal di dataran rendah.(7)

Penelitian yang dilakukan Jaowenny dkk, menyimpulkan bahwa perkembangan rata-rata fungsi paru (FVC, FEV-1) pada orang yang tinggal di dataran tinggi lebih besar daripada fungsi paru (FVC, FEV-1) orang yang tinggal di dataran rendah. Hal ini berarti makin rendah tekanan udara di suatu daerah akan diikuti pula peningkatan fungsi paru (FVC, FEV-1).(8)

\section{METODE PENELITIAN}

Penelitian ini adalah jenis penelitian deskriptif dengan menggunakan tabel distribusi frekuensi,.Populasi dalam penelitian ini adalah seluruh warga desa yang memenuhi kriteria inklusi.Jumlah sampel sebanyak 30 orang.Pengambilan sampel menggunakan metode non random sampling (purposive sampling).

\section{HASIL PENELITIAN DAN PEMBAHASAN}

Tabel 1. Distribusi subjek berdasarkan umur

\begin{tabular}{ccc}
\hline $\begin{array}{c}\text { Umur } \\
\text { (Tahun) }\end{array}$ & $\mathbf{n}$ & $\mathbf{\%}$ \\
\hline $20-30$ & 1 & 3,3 \\
$31-40$ & 7 & 23,3 \\
$41-50$ & 11 & 36,7 \\
$51-60$ & 7 & 23,3 \\
$61-70$ & 4 & 13,3 \\
\hline
\end{tabular}

Tabel 1 menunjukkan umur subjek penelitian dengan distribusi terbanyak pada 
umur 40-50 tahun dengan jumlah 11 orang (36,7\%) dan yang paling sedikit yaitu 20-30 tahun dengan jumlah 1 orang (3,3\%). Usia berhubungan dengan proses penuaan atau bertambahnya umur. Seiring bertambahnya umur, secara fisiologis, fungsi paru menurun baik kemunduran struktur maupun kemunduran fungsi.Penurunan tersebut dikarenakan menurunnya elastisitas paru dan meningkatnya kekakuan dinding dada. Kebutuhan zat tenaga terus meningkat sampai akhirnya menurun setelah usia 40 tahun dikarenakan telah menurunnya kekuatan fisik. Dalam keadaan normal, usia juga mempengaruhi frekuensi pernapasan dan kapasitas paru. Frekuensi pernapasan pada orang dewasa antara 12-20 kali permenit, pada anak-anak sekitar 24 kali permenit sedangkan pada bayi sekitar 30-40 kali permenit. Mulai dari fase anak-anak sampai dewasa terjadi pertumbuhan paru sehingga pada waktu itu nilai fungsi paru semakin besar bersamaan dengan pertambahan usia. Beberapa waktu nilai fungsi paru menetap kemudian menurun secara perlahan-lahan, biasanya umur 30 tahun sudah mulai mengalami penurunan.Menurut suatu teori, semakin tua umur seseorang maka semakin besar kemungkinan terjadi penurunan fungsi paru. Hal ini didukung dengan peneltian sebelumnya, bahwa semakin bertambah usia maka akan dapat menurunkan fungsi paru seseorang seseorang $(9,10)$

Tabel 2. Distribusi subjek berdasarkan pekerjaan

\begin{tabular}{ccc}
\hline Pekerjaan & n & \% \\
\hline IRT & 14 & 46,7 \\
Petani & 11 & 36,7 \\
Pensiunan & 1 & 3,3 \\
PNS & 1 & 3,3 \\
Swasta & 3 & 10 \\
\hline
\end{tabular}

Tabel 2 menunjukkan pekerjaan subjek penelitian dengan distribusi terbanyak pada pekerjaan ibu rumah tangga (IRT) dengan jumlah 14 orang $(46,7 \%)$, diikuti dengan petani sebanyak 11 orang $(36,7 \%)$ sedangkan yang paling sedikit pada pekerjaan pensiunan dan pegawai negeri sipil (PNS) dengan jumlah 1 orang (3,3\%). Seseorang yang mempunyai aktivitas tubuh cukup tinggi, seperti petani atau atlet, frekuensi pernapasannya akan lebih tinggi daripada seorang sekretaris yang cenderung melakukan aktivitas pekerjaannya dengan duduk. Hal ini disebabkan energi yang diperlukan oleh seorang petani atau atlet lebih banyak dibandingkan oleh seseorang yang beraktivitas dengan cara duduk. Riwayat pekerjaan yang berhubungan dengan debu berbahaya dapat menyebabkan gangguan paru.Hal ini didukung dengan penelitian dari Yulaekah S, bahwa semakin lama seseorang terpapar debu berbahaya maka semakin besar kemungkinan terjadi gangguan pernapasan. Apabila kondisi paru terpapar dengan berbagai komponen tercemar, fungsi fisiologis paru sebagai organ utama pernapasan akan mengalami berbagai gangguan (11).

Tabel 3. Distribusi subjek berdasarkan indeks massa tubuh (IMT)

\begin{tabular}{cccc}
\hline IMT & Kategori & $\mathbf{n}$ & $\mathbf{\%}$ \\
\hline$<18,5$ & Underweight & 0 & 0 \\
$18,5-$ & Normal & 5 & 16,7 \\
22,9 & $\begin{array}{c}\text { Kelebihan berat } \\
\text { badan }\end{array}$ & 0 & 0 \\
23,0 & $\begin{array}{c}\text { Beresiko menjadi } \\
\text { obes }\end{array}$ & 5 & 16,7 \\
$24,0-$ & Obes I & 15 & 50 \\
$25,0-$ & Obes II & 5 & 16,7 \\
29,9 & & & \\
$\geq 30,0$ & &
\end{tabular}

Tabel 3 menunjukkan indeks massa tubuh (IMT) subjek penelitian dengan distribusi terbanyak pada obes I dengan jumlah 15 orang (50\%) dan yang paling sedikit yaitu pada normal, beresiko menjadi obes dan obes II dengan jumlah 5 orang (16,7\%). Tidak ada subjek penelitian yang masuk kategori underweight.Meningkatnya jumlah lemak di dinding dada dan abdomen, kemungkinan mempunyai efek pada sifat mekanik dada dan diafragma serta menunjukkan adanya perubahan fungsi pernafasan.Hal ini menurunkan volume paru 
dan perubahan gambaran ventilasi pada setiap respirasi. Selanjutnya, peningkatan jumlah massa lemak menunjukkan "compliance" sistem pernafasan secara luas dan pengurangan yang lebih besar dapat dilihat pada dinding dada dari paru. Penimbunan massa lemak ini menunjukkan elastisitas dan kemampuan sistem pernafasan, sehingga otot-otot pernafasan bekerja lebih keras guna mengatasi rekoil elastis yang berlebihan. Jadi pada obesitas, "compliance" dinding dada menurun, kerja pernafasan meningkat dan volume residu pernafasan serta kapasitas vital paru menurun. Disfungsi dinding dada dan otototot dinding abdomen akan mengakibatkan gangguan fungsi paru obstruktif dan pengurangan volume paru sehingga terjadi penurunan nilai FEV-1.(12,13)

Tabel 4. Distribusi frekuensi berdasarkan derajat FEV-1

\begin{tabular}{ccc}
\hline $\begin{array}{c}\text { Tipe obstruktif } \\
\text { FEV-1 (\%) }\end{array}$ & n & \% \\
\hline Normal $(>75)$ & 29 & 99 \\
Ringan $(60-75)$ & 1 & 1 \\
Sedang $(40-59)$ & 0 & 0 \\
Berat $(<40)$ & 0 & 0 \\
\hline
\end{tabular}

Tabel 4 menjelaskan tentang distribusi frekuensi responden berdasarkan derajat obstruktif FEV-1 sesuai pada hasil pemeriksaan FEV-1. Paling banyak dengan nilai normal (>75 \%) yaitu 29 orang (80\%), dikuti dengan ringan (60-80) yaitu sebanyak 1 orang (1\%). Tidak ada subjek penelitian yang memiliki nilai sedang (40-59) dan berat $(<40)$.

\section{SIMPULAN}

Dari hasil penelitian yang dilakukan pada warga desa Rurukan, didapatkan paling banyak nilai FEV-1 normal (>75 \%) yaitu 29 orang (80\%), dikuti dengan obstruktif ringan (60-80) yaitu sebanyak 1 orang (1\%). Tidak ada subjek penelitian yang memiliki nilai obstruktif sedang (40-59) dan obstruktif berat $(<40)$.

\section{DAFTAR PUSTAKA}

1. Guyton \& Hall (2007). Buku Ajar Fisiologi Kedokteran. Edisi 11. Jakarta. EGC; 2007

2. World Health Organization. Respiratory System. Available from: http://who/respiratory_system

3. Djojodibroto D. Respirologi. Jakarta: Penerbit buku kedokteran EGC; 2009

4. M.R. Miller, R. Crapo, J. Hankinson, V. Brusasco, F. Burgos, R. Casaburi, et al. General considerations for lung function testing. Eur Respir J 2005; 26 p.153-161

5. West J.B. Respiratory Physiology, 6th ed. Baltimore: Williams and Wilkins; 2003

6. Adien Gunarta. Dataran Tinggi, Dataran Rendah dan Bukit. Available from: http://id.scribd.com/doc/24581115/datarantinggi-rendah-dan-bukit

7. Janatin Hastuti. Ukuran dan Bentuk Dada Penduduk di Dataran Tinggi Samigaluh dan Dataran Rendah Galur Kulon Progo Yogyakarta. Available from: http://jurnal. ugm.ac.id/index.php/jai/article/view/1145

8. I Nyoman Sudarmada. Perkembangan Kapastitas Vital Paru Anak Usia 6-12 Tahun. Available from: http://journal. unnes.ac.id/nju/index.php/miki

9. Joko Suyono. Deteksi Dini Penyakit Akibat Kerja. Jakarta : EGC.2001.

10. Siti Muslikatul Mila. 2006. Hubungan Antara Masa Kerja, Pemakaian APD Pernapasan Dada Tenaga Kerja Pengamplasan Dengan Kapasitas Fungsi Paru PT. Ascent House Pengangaan Jepara. Skrpsi. UNNES.

11. Siti Yulaekah. Paparan debu terhirup dan gangguan fungsi paru pada pekerja industri batu kapur. Available from: http://eprints.undip.ac.id//18220/1/Siti_Yul aekah.pdf

12. Praud JP, Canet E. Chest Wall Function And Dysfunction. Piladelphia : Elsevier Inc; 2006;733-43

13. Siregar F. Perbandingan Arus Puncak Ekspirasi Sebelum dan Sesudah Latihan Fisik Pada Anak Obesitas Dan Tidak Obesitas. Medan: Bagian Ilmu Kesehatan Anak Fakultas Kedokteran Sumatera Utara, 2007 